\title{
Immunocytochemical Observation of Adenohypophysis in a Human Growth Hormone (hGH) Gene Transgenic Mouse
}

\author{
Shin TANAKA, Fumihiko SASAKI*, Hideaki TOJO**, and Akio MATSUZAWA \\ Laboratory Animal Research Center, the Institute of Medical Science, The University of Tokyo, \\ 4-6-1 Shirokanedai, Minato-ku, Tokyo 108, *Department of Veterinary Anatomy, \\ College of Agriculture, University of Osaka Prefecture, 1-1 Gakuen-cho, Sakai-shi, \\ Osaka 593, and ${ }^{* *}$ Laboratory of Applied Genetics, Department of \\ Animal Resource Science, The University of Tokyo, \\ 1-1-1 Yayoi, Bunkyo-ku, Tokyo 113, Japan
}

(Received 13 November 1992/Accepted 17 February 1993)

\begin{abstract}
Adenohypophysis was immunocytochemically examined in an infertile female transgenic $(\mathrm{Tg})$ mouse which carried human growth hormone $(\mathrm{hGH})$ gene and had a high circulating level of hGH. No GH positive cells were detected. This confirmed the extrahypophyseal (ectopic) production of hGH and was coincident with the disappearance of parenchymal cells showing affinity to azocarmine in Azan staining. The normal frequency of ACTH positive cells was in accordance with the previous suggestion based on the changes found in zona fasciculata cells of the adrenal cortex. Most interesting findings were the detection of many PRL positive cells and the ovarian histology with nearly normal characteristics except for the presence of thick capsule and interstitial gland-like structure composed of large and light cells. Ovarian histology was also clearly different among individual $\mathrm{Tg}$ mice, even though they stemmed from the same line or progenitors, and had a similar phenotype. The current immunocytochemical observation well documented the changes revealed with Azan staining in the adenohypophysis about GH but not about PRL or ACTH. Thus, the immunocytochemical analysis of the adenohypophysis will provide useful methodology in assessment of endocrinological circumstances of Tg mice.- KEY WORDS : adenohypophysis, hGH transgenic mouse, immnunocytochemistry, ovarian histology
\end{abstract}

\section{ヒト成長ホルモン $(\mathrm{hGH})$ 遺伝子導入マウスの下垂体}

田中 憤・佐々木文彦*・東條英昭**・松沢昭雄

\author{
東京大学医科学研究所実験動物研究施設 \\ *大阪府立大学農学部家畜解剖学 \\ **東京大学農学系研究科応用遺伝
}

組換え外来遺伝子を導入したトランスジェニック $(\mathrm{Tg})$ 家畜を作出しようとする目的の 1 つに, 医学上重 要な生理活性物質を乳腺で産生させ, 乳汁から回収し
ようとする試みがある $[12]$ 。東條はマウス乳腺でヒト 成長ホルモン $(\mathrm{hGH})$ を産生させることを目的として, マウス乳清酸性蛋白 (mWAP) 遺伝子と hGH 遺伝子 
の融合遺伝子を導入した Tg マウスを作出した $[12$ ， 13]。この Tg マウスでは, 循環血と同様乳汁中でも高 濃度の hGH が検出された $[12,13]$ 。そのような $\mathrm{Tg}$ マ ウスの雌は不妊を呈し, 乳癌を発生する個体がいくつ か見られた[13]。不妊で乳癌を伴う Tg マウスの卵巣 では，卵胞が少なく黄体が認められなかった。下垂体 前葉ではアザン染色でアゾカルミンに染色される細胞 が殆ど消失していた。それ故, 高濃度で検出された hGH は, 下垂体由来でなく乳腺等異所性のものである と解釈された $[13]$ 。更に副堅皮質では，束状層で細胞 の肥大と脂肪滴の異常な增加がみられ, 典型的な網状 層が存在しなかった $[10]$ 。この束状層細胞の变化は, 機能が高まっているとされる像と類似していたが, 脂 肪滴が多すぎ，末梢血中のコルチコイドも測定してい ないので，一義的には高 hGH による影響と解釈され た[10]。また乳癌が発生したことから PRLの動態が 注目された。ラットでは GH と PRLの受容体が類似 し[2]，エストロジェンの作用下では下垂体の GH 産 生細胞が PRL 産生細胞へ変化するとの論議もある [9]が,一般的にはこの変化は認められていない $[7,8]$ 。 高濃度の hGH が循環している Tg マウスでは, 内因 性 PRL は低いが hGH の PRL 様作用のため生理的に は高 PRL 状態であることが報告された $[4,5,6]$ 。今回 の Tg マウスでも, 卵巣の所見から PRL は增加してい ると推定された[13]。実験的に高 PRL 状態であるこ とが知られているマウスで, 電顕レベルの形態と計測 から高 PRL が証明された個体の卵巣は多数の卵胞を 含んでいたが黄体を全く欠いていた[14]。

これら下垂体の機能状態について考察された点 $[10$, 13]を確認する目的で, 前報[10]で副堅皮質の観察に用 いた個体 (245日秢，体重：53.8g, 下垂体：2.3mg, 卵 巣 : $67.1 \mathrm{mg}$,血中 $\mathrm{hGH}$ 濃度 $: 60.0 \mathrm{ng} / \mathrm{m} \ell)$ の下垂体 を GH，ACTH とPRLについて免疫組織学的に検索 した。更に PRLの状態を推定するため同個体の卵巣 も検索した。この個体は，(C57BL X DBA/2) F 肧へ 遺伝子を導入して得られた $3 匹 の$ 雄 $T g$ マウスの内5 ピーの導入遺伝子が検出されたもの(No. 3-1)を ICR 雌と交配して得た雌で，不妊で乳癌を伴っていた $[10$, 13]。

下垂体はブアン液で浸漬固定し，パラフィンに包埋 した後, $10 \mu \mathrm{m}$ の切片としてマウスの PRL $(1: 1,000)$, ラットの $\mathrm{GH}(1: 1,000)$, ヒトの $\mathrm{GH}(1: 1,000)$, ブタの $\operatorname{ACTH}(1: 3,000)$ に对する抗血清を用い，既報の方法 [7]に従って染色した。卵巣は同様に処理し，下垂体と
ともに $3 \mu \mathrm{m}$ の切片としてアザン染色を施した。

下垂体では，ラット $\mathrm{GH}$ 抗体陽性の細胞は全く検出 されなかった(Fig. 1)。ヒト GH 抗血清に対する陽性 細胞もほとんど観察されなかった。ACTH 抗血清に陽 性の細胞は前葉の中央部と周辺部に，少数認められた (Fig．2)。細胞の形状は一定せず不規則であった。中 間部が全体に弱く均一に染色された(Fig．2，In)。一 方, PRL 抗血清に陽性の細胞は腺全体に豊富に分布し ていた(Fig．3)。卵巣は水腫を伴い，卵巣軎が肥厚し ていた(Fig. 4, arrowheads)。卵巣内には大きな黄体 と末分化から成熟, 更に退行まで, 種々の段階の卵胞 が多数認められた(Fig. 4, L and F)。いくつかの黄 体は退行途中であり, 卵胞は卵巣の深部にも存在して いた。間質では細胞質が明るく，大型の細胞が集団を 形成していた(Fig. 4, Int)。下垂体のアザン染色標本 では，正常例でみられる多数の円形ないし棈円形でア ゾカルミンに濃染する細胞[13]が全く認められなかっ た(Fig. 5)。

東條により hGH 遺伝子を導入して作出された $\mathrm{Tg}$ マウスで[12]，乳汁あるいは循環血内で検出された高 濃度の hGH は，下垂体由来でなく既に示唆されたよ うに下垂体以外の組織に由来するものである [13]こと が免疫組織学的に確認できた。更に Tg マウス下垂体 の免疫染色で $\mathrm{GH}$ 細胞が欠如していたことは，アザン 染色でアゾカルミンに染色される細胞の欠如 [13]とよ く一致していた。ACTH 陽性細胞は, 少数で, 正常マ ウスのものと大差がないように思われ(未発表所見), シリアンハムスターで報告された所見ともほほ同様で あった $[3,11]$ 。更に副堅皮質の束状層細胞の変化を， $\mathrm{ACTH}$ を介さないhGH の作用と解し，下垂体の $\mathrm{ACTH}$ 細胞に顕著な变化はないだろうとの前報の推 定 $[10]$ とも一致した。予期していなかった結果は, 多 数の PRL 陽性細胞が検出されたことと，卵巣の所見 である。PRL 陽性細胞の頻度は，実験的に高 PRL 状 態であることが明らかなマウス 114$]$ のそれと同様であ った。高濃度の異所性 $\mathrm{hGH}$ が検出される $\mathrm{Tg}$ マウス では低 PRL 状態となることが報告されている $[4,5$, 6]。その結果 GTH 分泌が变化し, 卵巣に異常をきたし て，無排卯あるいは発情周期が伸びて不妊となると説 明されている $[1,6]$ 。一方, 今回の $\mathrm{Tg}$ マウスは卵巣に 黄体が存在しないことから高 PRL 状態であろうと推 定されてきた[13]。本報で検索に供した Tg マウスも 高 hGH が検出された個体である。その下垂体では多 数の PRL 陽性細胞が検出され, 卵巣は裹の肥厚と特 
異な間質を除けば卯胞と黄体は正常例と同様に存在し た。ただ大型の卵胞が腺周辺部だけでなく，腺中心部 にも存在したことは正常例と異なっていた。周知のよ うに光顕レベルでの組織化学的手法では, 細胞内に陽 性物質が貯留していることまでは確認できるが，その 物質が分泌されていることを証明するにはRIA で末 梢血内の濃度を測定したり, 電顕レベルで分泌像の増 加を確認しなくてはならない。更に Tg マウスを作出 するために使用された系統の PRLの傾向も把握して おかなければならない。それ故この Tg $\mathrm{T}$ マウスでの PRL 産生あるいは循環状態をにわかに推定すること は困難である。唯一明確なことは卵巣の所見が前報 [13]と全く異なっていたことである。同じラインに由 来し, 高 hGH や不妊といった表現型が同様でも卵巣 の所見には個体差のあることが判明した。今回の所見 は, 卵胞と黄体が正常例に近い状態であった。もう1つ 今回の $\mathrm{Tg}$ マウスに特異な点は間質に大型で, 明るい 細胞集団が存在したことである。これは前報の $\mathrm{Tg}$ マ ウスはおろか正常例でもみられないものである。間質 腺と推定されるが, 高 $\mathrm{hGH}$ ・乳癌或いは加齢との関連 から Tg マウスの贸巣での興味を今後につなぐもので ある。

今回の免疫組織学的検索で認められた变化の内 $\mathrm{GH}$ に関するものは, アザン染色の所見からある程度推測 できたが, PRLに関するものは全く予測すらできなか つた。それ故 $\mathrm{Tg}$ マウスの内分泌学的生理状態を組織 学的に解析するうえで免疫組織学的手法は極めて有効 であることが明らかとなった。

本検索で, (1) hGH 遺伝子を導入された Tg マウス で検出された高濃度の hGH は下垂体以外の器官で異 所性に産生されている可能性が高いこと, (2)同じライ ンに由来し, 同様な表現型を示す $\mathrm{Tg}$ マウス間でも, 卵 巣の変化に個体差の存在すること, (3) Tg マウスの内 分泌環境を評価するうえで下垂体の免疫染色は有効な 手段であることが明らかになった。更に例数を増して 検索を加えることは当然で hGH の検出, 下垂体, 副

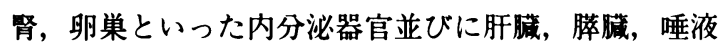
腺, 乳腺といった外分泌器官の形態をセットにして得 た所見の傾向から演繹的にその個体を評価し，これを 類別するような体制を作らないと, 折角 Tg マウスが 提示してくれた責重な情報を見落とすことになりかね ない。

\section{要 䄪}

ヒト成長ホルモン $(\mathrm{hGH})$ 遗伝子を導入して作出さ れたトランスジェニック ( Tg) マウスの腺性下垂体 を, 免疫組織学的手法で検索した。GH 陽性細胞は全く 検出されず，この Tg マウスで高濃度に検出された $\mathrm{hGH}$ は下垂体以外の器官に由来することが明らかと なった。ACTH 陽性細胞の分布様式と数に大きな变化 は認められず, 前に束状層細胞の所見から推定した状 態と一致した。一方 PRL 陽性細胞は多数検出された。 これは報告されている結果と一致しないので, 確認の ため卵巣を組織学的に検索したところ变性途上の黄体 が存在し, 卵胞はほほ正常であった。間質には大きな 明るい細胞が集団を形成していた。不妊と高 hGH を 示し, 同一ラインに由来していても今回の $\mathrm{Tg}$ マウス 間では卯巣の組織学的所見に相当個体差のあることが 判明した。

広範な御指導をいただいております名古屋大学名誉教授近藤 恭司先生並びに藤岡俊健先生に心から感謝致します。依頼された 事柄に対しては例数は少なくとも责任を持った対応をすべきで あるとの御指導・御督励をいただき本報のきっかけを与えていた だきました本所獣医学研究部教授豊田裕先生に感謝致します。

マウス PRL 抗体, ラット GH 抗体, hGH 抗体, ブタ ACTH 抗 体をそれぞれ分与賜った河本謷先生 (東京大学), 妹尾久雄先生 (名古屋大学), NIDDK, 井上金治先生(群馬大学)に感謝致しま す。

\section{文献}

[1] Bartke, A., Steger, R. W., Hodges, S. L., Parkening, T. A., Collins, T. J., Yun, J. S., and Wagner, T. E. (1988).J. Exp. Zool., 248, 121-124.

[2] Boultin, J.-M., Jolicoeur, C., Okamura, H., Gagnon, J., Edery, M., Shirota, M., Banville, D., Dusanter-Fourt, I., Djiane, J., and Kelly, P. A. (1988). Cell, 53, 69-77.

[3] Campbell, G. T., Wagoner, J., Borer, K. T., Kelch, R. P., and Corley, K. (1986). Cell Tissue Res., 245, 673-679.

[4] Chandrashekar, V., Bartke, A., and Wagner, T. E. (1988). Endocrinology, 123, 2717-2722.

[5] Chandrashekar, V., Bartke, A., and Wagner, T. E. (1991). Biol. Reprod., 44, 135-140.

[6] Chandrashekar, V., Bartke, A., and Wagner, T. E. (1992). Endocrinology, 130, 1802-1808.

[7] Sasaki, F., and Iwama, Y. (1988). Endocrinology, 123, 905-912.

[8] Shiino, M., and Renels, E. G. (1976). Anat. Rec., 185, 31-48.

[9] Stratmann, I. E., Ezrin, C., and Sellers, E. A. (1974). Cell Tissue Res., 152, 229-238.

［10］田中 慎·東條英昭·松沢昭雄 (1993). 実験動物, 42, 237- 
241.

[11] Taniguchi, K., Kanezaki, S., and Mikami, S. (1989). Jpn. J. Vet. Sci., 51, 893-903.

[12］東條英昭 (1992)。家畜繁殖誌, 38, J133-J142.
[13] Tojo, H., Tanaka, S., Matsuzawa, A., Takahashi, M., and Tachi, C. J. Reprod. Dev. in press.

[14] Yamaji, A., Sasaki, F., Iwama, Y., and Yamauchi, S. (1992). Anat. Rec., 233, 103-110.

\section{Explanation of Figures}

Adenohypophysis and ovary from an infertile female hGH transgenic mouse aged 245 days.

1. Adenohypophysis immunostained with anti-rat $\mathrm{GH}$ serum. Note the absence of immunoreactive cells in both pars distalis and pars intermedia (In). 2. Adenohypophysis immunostained with anti-porcine ACTH serum. Note the scattering of several positive cells at the central part of the gland and the positive reaction in the pars intermedia. 3. Adenohypophysis immunos- tained with anti-mouse PRL serum. Note the presence of many positive cells. 4. Ovary stained with Azan. Note the presence of many follicles (F), corpora lutea (L), light and large interstitial cells filling up the interstitium (Int) and thick capsule (arrowheads). 5. Adenohypophysis stained with Azan. Note the absence of cells stained with azocarmine. 1-3 and 5: Same magnification and orientation. Bar : $100 \mu \mathrm{m}$. 

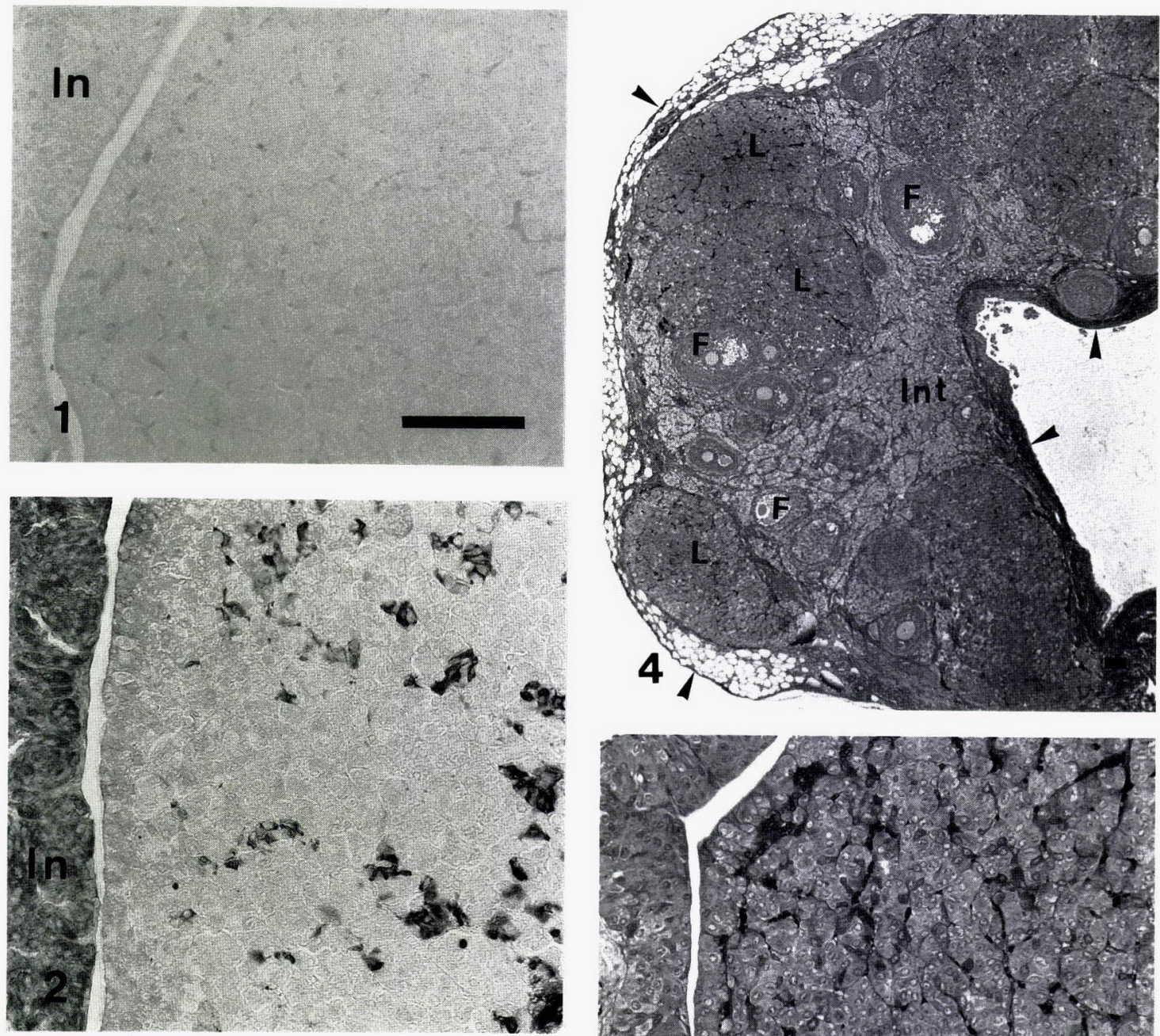

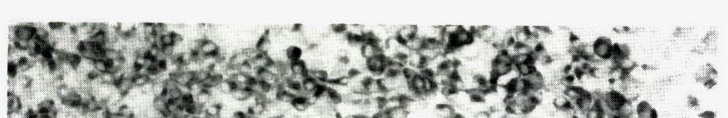
$\mathrm{Ce}^{2} \mathrm{y}$.

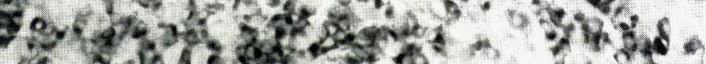

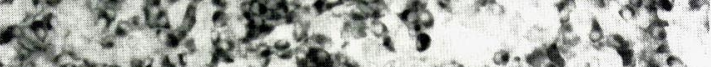

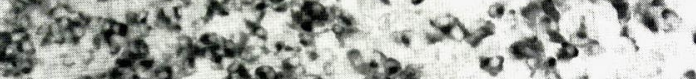

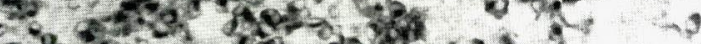

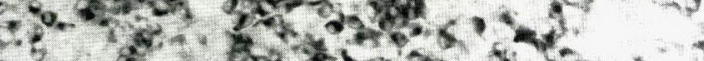

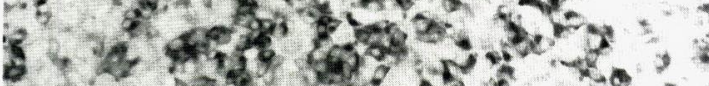

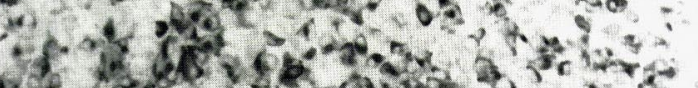

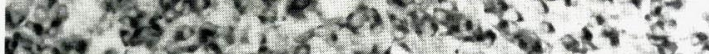

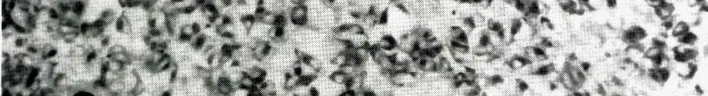

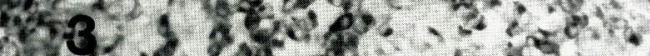

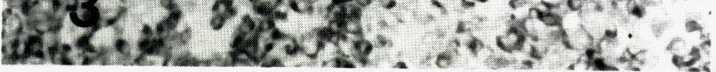

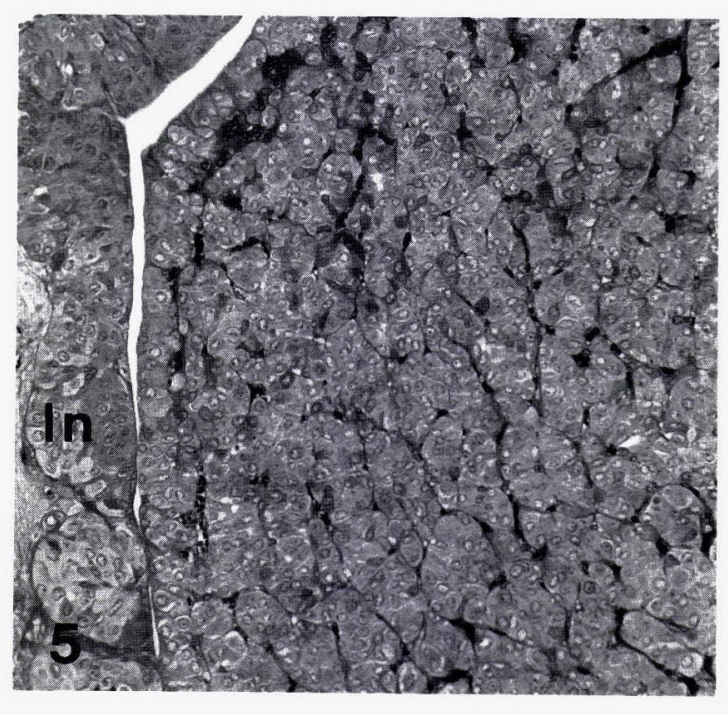

Fig. 1.

Fig. 2.

Fig. 3.
Fig. 4. 